\title{
Critical Success Factors Affecting E-Government Policy Implementation in Pakistan
}

\author{
Waqar Siddique
}

Graduate School of Governance, SungKyunKwan University Seoul, Republic of Korea,waqarsiddique1@gmail.com

Abstract: This research turns e-government policy into practice in two ways, firstly to distil the lessons from existing evidence and experience about e-government implementation of policies and secondly by assessing the quality of the evidence, gaps in the existing research, and ways that research findings can support the implementation process in Pakistan. The main question, therefore, is how far national policy aspirations translate into actions, which are meaningful, tangible and measurable at a local level. This means the consistency of the goals at all levels remain the same i.e., macro and micro levels. This study identifies critical factors that determine the faith of policy implementation in Pakistan. The proposed model, which is based on these critical factors, is validate by analyzing different hypothesizes using empirical analysis i.e., quantitative and qualitative. This study provides a fair idea about intrinsic and extrinsic behavior of these critical success factors towards e-government policy implementation concerning Pakistan. This study also facilities successful e-government implementation in Pakistan by setting direction and guidelines for all implementation stakeholders.

Keywords: e-government; e-government policy implementation; critical factors for successful egovernment implementation; critical factors

\section{Introduction}

\subsection{Background of the Study}

The development of infrastructure (communication, ICT etc) and institutions that aid the government in good governance have posed a major problem since Pakistan was founded. In this regard, different policies and programmes are launched from time to time.

Most of its policies tend to fail in the implementation phase. For example, most of Pakistan's educational policies were abandoned due to weak policy implementation that did not achieve the desired result and objectives. Similarly, different mega projects have failed like the Social Action 
Programme (SAP I and II), the Sindh Primary Education Development Project (SPEDP), the Girls Primary Education Development Project I and II (GPEDP), the Primary Education Curriculum Reform Project (PECRP) etc (Mustafa, 2004). Likewise, numerous teacher education programmes carried out by the government were found to be incompatible with the stated goals of policies (AKUI and DID, 2003, p. 3). The same is the case with the implementation of health policies as the government of Pakistan has undertaken many initiatives like the Rural Health Programme, the Polio Eradication Programme, and the Basic Health Programme among others, only for these initiatives to eventually fail. Finally, e-government programmes intended to create good governance are also telling the same story.

In 2002, a specialized e-government department named the Electronic Government Directorate (EGD) was set up under the supervision of the Ministry of Information Technology. The basic task of this department was to develop a participatory government in which citizens can interact with the government, assist in government affairs, and have access to information via the internet at their doorstep. To accelerate the performance of the EGD, the government developed a five-year electronic government plan in 2005. With the collaboration of the Ministry of Information Technology and other divisions, the plan targeted different areas of electronic governance, including the development of basic infrastructure to link all government departments and ministries with the federal government's data centre, the development and implementation of standard software for internal communication, human resource, budget, project management, document/file management, different e-services etc. As of the year 2000, the Ministry of IT and Telecomm has allocated Public Sector Development Programme (PSDP) funds of amount Rs. 3.68 billion for e-government and IT sector development; out of the said amount Rs. 281 million was specifically utilized for e-government projects. E-Government projects are still in the implementation pipeline being worth about Rs. 1.5 billion (Hameed, 2007).

Despite resources and government backing, EDG badly failed to produce the desired results. Policies in this case still do not convert into reality as e-government has become elusive to the people of Pakistan (Ahmed, 2012).

\subsection{Objective of the Study}

Makinde (2005) identifies some implementation problems of policy, including corruption, lack of continuity and consistency in government policies, inadequate human and material resources etc, all of which often lead to an implementation gap, i.e., the widening distance between stated policy goals with respect to realization.

The goal of this research is to turn e-government policy implementation into practice in two ways. Firstly, to distil the lessons from existing evidence and experience about e-government implementation of policies and, secondly, by assessing the gaps and critical success factors that need to be addressed for effective policy implementation process in Pakistan.

This study will help in determining how government policy does or does not translate into practice and the factors that help or hinder policy implementation process. Additionally, the study 
will identify criteria that lead to the success or failure of policy implementation. This research will help the decision maker to make better decision. Government always assumes that its policy framework is clear and unambiguous so it holds the implementer responsible for better policy implementation. That is why implementers are always considered to be at fault when a policy fails, but in the case of success, the story may be different.

\section{Literature Review}

E-government policy implementation is a very complex and continuous process as it inevitably takes diverse shapes and forms in accordance with different conditions and institutional settings (Paudel, 2009). The main turning point is when government processes have been transformed into best governance activities (Hill, and Hupe, 2009). Implementation can be defined as a process of execution that lies under the boundary of policy statute and is initiated by executive or court orders (Mazmanian, et al, 1983). It can also be defined as the actions performed by certain people to achieve set objectives and targets describe in the policy decision document (Van Meter, et al, 1975). Finally, implementation has also been defined as an intention of government by setting a certain line of action (O Toole, 2000).

The line between public policy administration and policy implementation is still blurred in the research, as both interlink disciplines although they have different dynamics. This is the main root cause of not finding a significant analytical framework that purely deals with policy implementation (Pressman and Wildavsky, 1973, p. 166).

A success related to policy implementation can be defined as an achievement of a target/action within a specified objective and goals in the set period of time or parameters. Success can be include an entire project or it can be restricted to a single component of a project or task. 'Policy' is defined as a systematic, organized, balanced and rational arrangement of activities in order to carry out the authoritative decisions in the light of statute (Giacchino and Kakabadse, 2003). In a top to bottom perceptive, outcomes determine success and in a bottom to top perspective, effects on the target audience determine the success (Palumbo, el at, 1984). Similarly, the term 'successful implementation' is also quantifiable under certain criteria. Successful implementation as organizations that meet the targets set in statutes or strategic actions taken by the administrative arm of government or organization in order to deliver the intended policy decision and to have achieved the planned outcomes. Success factors are defined as controllable basic components of the work in a project, or the management process to raise the chances of achieving a successful outcome (Giacchino and Kakabadse, 2003).

Matland (1995, p.145) proposed the ambiguity and conflict model by combining the top-down and bottom-up models. In this model, relative value is based on the degree of ambiguity in goals, means of a policy, and degree of conflict. Four policy implementation paradigms are defined in this model: low conflict-low ambiguity (administrative implementation), high conflict-low ambiguity (political implementation), high conflict-high ambiguity (symbolic implementation) and low conflict-high ambiguity (experimental implementation). Ambiguity and conflict directly 
influence the policy implementation and this model provides a more theoretically grounded approach to implementation.

Three major activities that play a major role in policy implementation have been identified: policy interpretation, organization and application. Actors are defined as those who are interacting for the purpose of putting a programme in to effect or involved with implementation processes. It is not easy to generalize policy actors due to the huge diversity of each policy and its implementation even within e-government domain. Generally, bureaucrats, legislators, judges, political people, private citizens, private groups, interest groups, non-governmental agencies, government agencies, and the private sector are considered to be major e-government policy actors. There are a great deal of best practices and techniques for effective e-government policy implementation. Policy implementation incorporated with project management or Management by Objective (MBO) technique and procedures may bring positive results. Major policy implementation influential factors are categorized as external factors that cannot control by management efforts and internal factors that can improve performance and efficiency (Lee, et al, 2012)

\section{Research Design}

Since the topic is too broad and novel in Pakistan, the study will follow both quantitative and qualitative methods/approaches to validate the set hypotheses regarding the behaviour of independent variables with respect to dependent variables. This mix method is commonly referred to as sequential procedures, in which the researcher seeks to elaborate or expand the findings of one method with another. This technique is being adopted to avoid weaknesses of either approach alone and to obtain maximum valid findings. As a quantitative measure, more than 150 diverse qualified and experienced people will be applied to in the survey, which includes policy makers, university professors, politicians, government officers, IT experts and bankers in Pakistan. The results of the survey will be statistically analysed in order to determine the relationship between dependent and independent variables. At the same time, telephone interviews of some policy makers/implementers in Pakistan will be conducted to qualitatively expand the findings of survey results for a sound conclusion. Similarly, different case studies of policy implementation in Pakistan will be organized to prove the hypothesis by using different evidence.

A conceptual framework is a presentation that "explains, either graphically or in narrative form, the main things to be studied- the key factors, concepts, or variables- and the presumed relationship among them" (Miles and Huberman, 1994, p.18). Many factors influence the process of policy implementation of public policies. Academic researchers have analysed public policy implementation process by defining descriptions of implementation styles and structures, the roles of implementing actors, and ways of evaluation of public policy implementation. Previous problems experienced along with the current issues occurring during policy implementation processes may act as a catalyst in better transformation of policy inputs into desired outputs (Kiviniemi, 1986). Since 1986 O'Toole's has analysed different policy implementation studies and has found more than three hundred variables (Matland, 1995). 
The proposed model, based on a literature review in context with Pakistan, has been divided into nine independent variables and one dependent variable. Again, independent variable are grouped together in three clusters. Factors like e-leadership, policy elucidation, strategic planning are assigned to the category Organization Oriented Factor. While, resourcing, communication and coordination, role delineation with accountability are bundle together in the category Process Oriented Factor. Commitment and motivation, skills and abilities, and trust are clustered together to form the People Oriented Factor category. The framework comprises two concepts: successful factors for e-government policy implementation in Pakistan and the success of e-government policy implementation in Pakistan. Successful e-government policy implementation is considered to be a dependent variable, whereas nine important factors are considered to be independent variables. These factors are e-leadership, policy elucidation, strategic planning, resourcing, communication and coordination, role delineation with accountability, commitment and motivation, skills and abilities, and trust.

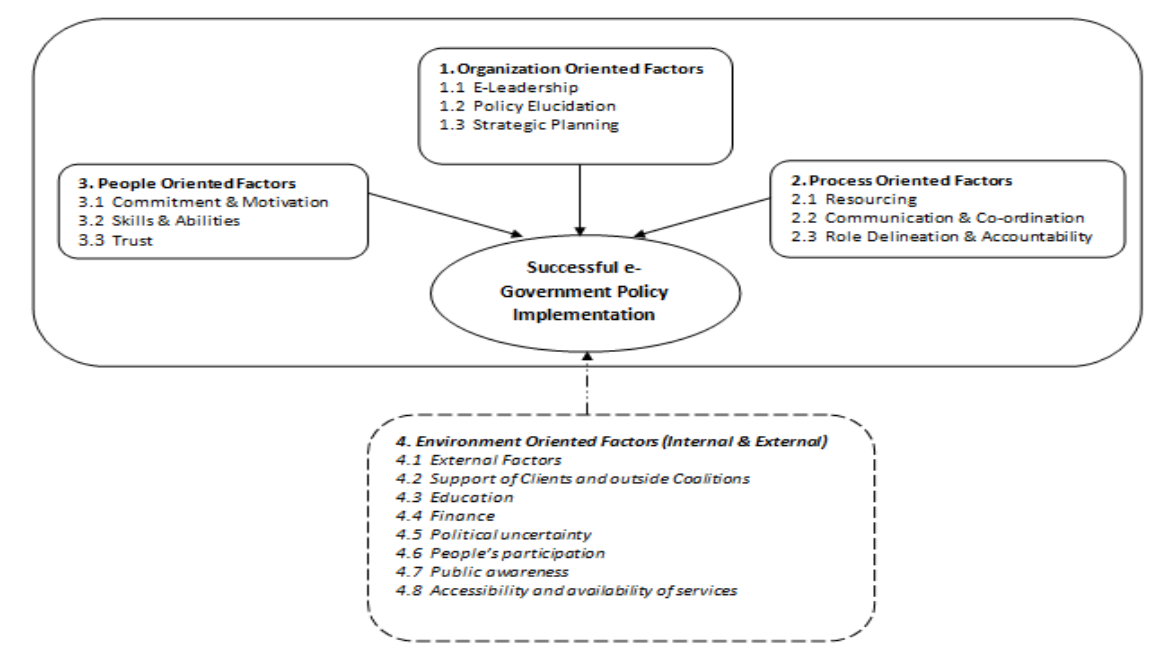

Figure 1: Conceptual Framework

\subsection{Organizational Factors}

The role of e-leadership is crucial in the implementation process of public policy. (Robichau and Lynn, 2009). It is natural that new digital immigrants may resist certain change but e-leadership coupled with e-vision can drive things more smoothly. True to the phrase "lead from the front", an e-leader needs to exhibit a strong will for undertaking and executing e-government projects under the tag of policy implementation. The goals of electronic leadership stay the same for a common leader. Additionally, it is necessary to implement a set goals digitally with computer-based, mediated virtual teams/groups that may be dispersed over different regions/offices. However, electronic leaders also face multiple new challenges, for example, how to bridge the physical distance from their respective subordinates, how to communicate effectively with far-flung teams members; how to covey keenness and eagerness and inspire followers electronically, and how to build trust with colleagues posted in the remote regions. Therefore, to amicably tackle such issues, e-leaders must have a clear-cut plan for every aspect of the system (Yildiz, 2006). 
According to (Matland, 1995) it is not possible to separate the political and administrative functions of leadership. E-leadership has to cope with both sides of administration, i.e., political and administration. This role also includes acquiring resources from the external environment to overcome the shortage and to mobilize all resources efficiently

Based on the above literature discussion, one can make the following hypothesis:

H1 E-leadership's role is likely to have a positive effect on successful ea: government policy.

Successful policy implementation is completely based on policy statute and its elucidation. As to how effective policy clarity is, policy implementation becomes simpler, more straightforward, easier, more realistic and more successful (Brynard, 2005). Major implementation problems occur due to local bureaucrat or implementing agents' understanding or misunderstanding (James et al., 2002). In this regard, policy elucidation is very critical and sensitive as it provides an understanding about policy and its objectives at all implementation levels.

The criteria for the interpretation of successful policy implementation is defined by the extent of which the terms of reference of policy to be implemented are adequately addressed and similarly the degree by which it also delivers the expected 'functionality' to the target audience (Giacchino and Kakabadse, 2003). Policy documents always play a central role in policy implementation. They act like a constitution for all stakeholders. Policy statute is a starting point and its elucidation determines success and failure (Mazmanian and Sabatier, 1983, pp. 20-21; May, 2008).

Matland (1995) argues that the language used in statute is often vague ambiguous and contradictory for passing of legislation. Therefore, for successful policy implementation it is the duty of the executives to make this approved policy clear, understandable, simple and transparent at all levels of implementation.

According to the Economist Intelligence Unit report (2010), due to policy inconsistency, when policy contains discrepancies and contradictions in statute, it results in the failure of e-government policy implementation e-government policy implementation.

Based on above literature discussion, one can make the following hypothesis:

\section{H1 Clear and consistent policy guidelines lead toward the successful e-} .b: government policy implementation.

"If you cannot plan it, you do not do it" (Gichoya, 2005). Strategic planning is considered to be a key success factor for e-government policy implementation (Gichoya, 2005 and Maciaszek, 2001, p.10). To overcome different constraints, particularly time and money, strategic planning is required to make e-government policy implementation successful. Strategic planning covers whole implementation activities. It is mandatory to have an e-vision and e-strategic planning for smooth and effective e-government policy implementation. E-leaders must have the right strategic plan that encapsulates vision-based theoretical knowledge and ground realities. A vision document is the first step towards the e-government policy implementation. 
Strategic planning requires control and accountability functions. Control system involves many activities, e.g., defining clear objectives, tasks to be performed, job delegation, standardization of work, appropriate evaluation system, rewarding and punishment system (May, 2008). Success of policy implementation intrinsically depends critically on number of factors, e.g., local capacity, will, commitment and motivation determines the implementer's assessment to value the policy and, most important, the appropriateness of a strategy and planning (May, 2008).

In developing countries like Pakistan where resource are very limited, strategic planning plays an important role in context with e-government policy implementation. According to the Economist Intelligence Unit report (2010), poor planning is the leading cause of policy failure.

The above literature supports the following hypothesis:

$\mathrm{H} \quad$ Strategic planning has a positive effect on success of e-government policy 1.c: implementation.

\subsection{Process Oriented Factors}

Resources are the critical factor in implementing public policies. An organization's human resources can be regarded as the most important factor in implementing successful e-government policies. It includes the right size staff with proper and appropriate skills, information, authority, and facilities including building, equipment, land (Edwards, 1980, pp.53-82). It is assumed that agencies with greater internal resources have a greater chance to implement policy successful (Shull and Garland, 1995).

May (2008) describes how governments need to know about available resources and how to effectively utilize and mobilize these resources in successful e-government policy implementation.

Developing countries face many challenges in e-government policy implementation due to scarce resources. Kharel and Shakya (2012) have evaluated the case study of Nepal and found that better resources planning, organization and cost effective e-government policy implementation are the main factors that can lead towards success.

The above literature supports the following hypothesis:

H2 Proper and appropriate resources are likely to have a positive effect on .a: successful e-government policy implementation.

Implementation is a continuous process of interaction with a changing policy situation and intentions. Communication and coordination can be difficult to manage as target audiences interfere in implementation matters because governments want certain actions imposed on them. Similarly, at different points in implementation where the implementer finds it difficult to control a situation, useful and interactive communication is required at that time (Kiviniemi, 1986, p. 258).

According to Project Management Institution Inc, (2008), the greatest threat to the success of many e-government projects is a failure in communication management. Communications 
planning determines the information and communications needs of the stakeholders. Similarly, information distribution is the main feature of communication and coordination that needs to be addressed in a timely manner.

The above literature supports the following hypothesis:

H2 Strong communication and coordination is likely to have a positive effect on .b: successful e-government policy implementation.

Role delineation is defined as the clear allocation of role and job responsibility among individuals, teams and groups, particularly between politicians and civil servants in policy implementation process (Giacchino and Kakabadse, 2003).

The best way to counter or overcome the implementer's disposition (attitude, different perspective from decision makers, wrong use of discretion) is to define clear roles and responsibilities that should be closely monitored (Edwards, 1980). Another reason for failure of egovernment policy implementation is the lack of clear roles and responsibilities among different arms of the public sector, which thus creates political and bureaucratic obstacles, particularly in context with allocation of resources (Nagy et al, 2009). Another dimension of failure in egovernment policy implementation is due to the lack of segregation between policymaking and its implementation. Different implementation agencies find overlapping roles in this regard. This phenomenon leads to a situation where implementers fail to notice, intentionally ignore, or selectively attend policies that suit to their own interests (James et al, 2002).

The above literature supports the following hypothesis:

H2. Role delineation with accountability has a positive effect on success of ec: government policy implementation.

\subsection{People Oriented Factors}

The factors that determine commitment are often unclear. Commitment often depends on the implementer's unconditional ownership (Brynard, 2009). Commitment refers to the ability of the implementer to maintain focus on a policy initiative from its inception until delivery. There are differences in opinion about how to create sustainable commitment among policy implementers. One view is that political backing is required as commitment is considered to be a top-down issue (Giacchino and Kakabadse, 2003, p.146).

People are generally more inclined to show commitment to a high profile programme. On the other side, a higher and more visible profile of an e-government initiative leads greater pressure on implementers. However, this does not mean that a low-profile policy is necessarily doomed. Ownership of a programme reflects commitment at any level; this particularly implies to administrative and political ranks (Brynard, 2009). Maintaining continuous commitment and motivation among all stakeholders determines the assurance of policy implementation success. 
Commitment often fails, because decisions are postponed, not made, not taken at the right time, or ineffective (Brynard, 2009).

Motivation of policy implementers is higher where resources are sufficient as human's interest is naturally turned toward those e-government projects where resources and benefits are enormous (May, 2008). Motivation or will is influenced by factors largely beyond the reach of policy environmental stability, competing centres of authority, contending priorities or pressures and other aspects of socio-political settings which profoundly influence an implementer's willingness (May, 2008).

The above literature supports the following hypothesis:

H3 Strong commitment and motivation are likely to have a positive effect on .a. success of e-government policy implementation.

The use of technology by citizens is critical for successful e-government policy implementation. Computer literacy is defined as whatever a person needs to be able to retrieve information using internet and computers (Sulaiman el at., 2012). Similarly, it is important that everyone should use information or possibly possess the knowledge of information that is important for effective usage of e-government otherwise its utility will become useless (Hunter, 1983; Cole et al., 2004; Behrens, et al, 1994). Computer and information literacy are affected by literacy rate, age and gender of the citizens (Sobhi, et al., 2010). It is clear that without ICT skills and abilities, citizen are not able to take advantage of expensive e-government services (Al-Nuaimi, et al., 2011).

May (2008) points out that in keeping with a bottom up approach, a programme's success depends mainly upon the skills and professional knowledge of local bureaucrats. Therefore, skill set and education level of the local implementer is essential for effective depiction of policy implementation activities. Program success mainly depends on the expertise of individuals in local implementation structures, as they are responsible to exploit the local conditions for successful policy implementation wisely (Matland, 1995).

Thomas (1973, pp.197-209) argues that governments in developing nations are keen and show commitment to implement particular policy but public sector is not so much well equipped and capable to implement such policy successfully. This is happening due to the lack of profession knowledge and the necessary skill set required at each level for successful policy implementation. The implementing actors in most cases use intuition, spontaneous knowledge about job, legal concepts and formal rules against the described task and job responsibilities (Terpestra and Havinga, 2001, p. 97). James et al (2002) highlights that the implementing agents and agencies often lack certain factors like knowledge, skills, personnel and other resources necessary to work in a way that policy implementation demands (Firestone, 1989).

The above literature supports the following hypothesis:

H3 Skills and abilities have a positive effect on success of e-government policy .b. implementation. 
Trust refers to the extent that users believe that web sites or electronic services are legal, ethical, credible and protected. It is universally true that trust only exists in an uncertain and non-risky environment. Social factors, beliefs and expectations are considered to be important components for trust building in e-government policy implementation (Lean, et al., 2009).

E-government policy implementation critically depends upon the trust of the target audience. Technology adoption by the public depends on the trust of citizens in accurate information and secure transactions when using the internet (Belanger, F. and L. Carter, 2008).

Concerns about inadequate security and privacy safeguards in electronic networks can lead to distrust in applications of e-Government policy implementation, for example, unwarranted access to sensitive personal information or vulnerability to online fraud or identity theft etc. Similarly, trust leads toward the reliability issue. If people are used to e-services which are launched through successful e-government policy implementation then the reliability of these must not be comprised, otherwise trust will be destroyed. Citizens' positive perception on technology and on e-government applications, the quality and usefulness of e-Government services, the internet experience and propensity to trust, directly enhances the trust in e-Government policy implementation process (Colesca, 2009).

Citizens' trust in e-government has some unique features because of the impersonal nature of the online environment, the extensive use of technology, and the inherent uncertainty and risk of using an open infrastructure (Awadhi and Moris, 2008).

The above literature supports the following hypothesis:

$\mathrm{H} \quad$ Citizens' trust on e-government is likely to have a positive effect on successful 3.c. e-government policy implementation.

\section{Data Analysis and Findings}

Data was collected through survey questionnaires, which were first descriptively analysed and then statistically analysed using co-relation and regression tools. In the second part, a qualitative analysis of the issue was undertaken. The analysis is based on the data collected through telephone interviews of sixteen senior public officials involved in policymaking and implementation processes in Pakistan at different levels. In the third part, a critical review against the model's factor of different case studies of policy implementation in Pakistan was conducted

The proposed model is based on nine independent variables, which are grouped together into three major categories: Organization Oriented Factors, Process Oriented Factors and People Oriented Factors. Successful e-government policy implementation is based on these nine factors.

The conceptual and operational definitions of variables are as follows: 
Table 1: Conceptual and Operational Definition of Variables

\begin{tabular}{|c|c|c|c|}
\hline $\begin{array}{l}\text { Sr.No } \\
:\end{array}$ & Variables & Conceptual Definition & Operational Definitions \\
\hline 1. & E-Leadership & $\begin{array}{l}\quad \text { Electronic leader } \\
\text { necessitates implementation } \\
\text { on computer based } \\
\text { mediated virtual } \\
\text { teams/groups. }\end{array}$ & $\begin{array}{l}\text { Supervision, guidance/helping, } \\
\text { direction setting, support and } \\
\text { administration and project } \\
\text { management level. }\end{array}$ \\
\hline 2. & $\begin{array}{c}\text { Policy } \\
\text { Elucidation }\end{array}$ & Effective policy clarity. & $\begin{array}{l}\text { Clear policy understanding, policy } \\
\text { purpose and demands, effective policy } \\
\text { interpretation }\end{array}$ \\
\hline 3. & $\begin{array}{l}\text { Strategic } \\
\text { Planning }\end{array}$ & $\begin{array}{l}\text { Planning of whole } \\
\text { implementation activities. }\end{array}$ & $\begin{array}{l}\text { Setting of achievable milestones and } \\
\text { target, measurement of implementation } \\
\text { activities. }\end{array}$ \\
\hline 4. & Resourcing & $\begin{array}{l}\text { Resourcing means } \\
\text { structures, manpower, land, } \\
\text { equipment etc. }\end{array}$ & $\begin{array}{l}\text { Provision of project resources and its } \\
\text { utilization level. }\end{array}$ \\
\hline 5. & $\begin{array}{l}\text { Communicati } \\
\text { on and } \\
\text { Coordination }\end{array}$ & $\begin{array}{l}\quad \text { Continuous process of } \\
\text { interaction with all } \\
\text { implementation } \\
\text { stakeholders. }\end{array}$ & $\begin{array}{l}\text { Coordination and interaction level } \\
\text { between seniors, colleagues and juniors } \\
\text { along with external environment. }\end{array}$ \\
\hline 6. & $\begin{array}{l}\text { Role } \\
\text { Delineation with } \\
\text { Accountability }\end{array}$ & $\begin{array}{l}\quad \text { Clear allocation of role } \\
\text { and responsibility with } \\
\text { answerability against } \\
\text { assigned job. }\end{array}$ & $\begin{array}{l}\text { Efficiency and performance } \\
\text { evaluation and monitoring of work. }\end{array}$ \\
\hline 7. & $\begin{array}{l}\text { Commitment } \\
\text { and Motivation }\end{array}$ & $\begin{array}{l}\text { Willingness of the e- } \\
\text { government policy } \\
\text { implementer. }\end{array}$ & $\begin{array}{l}\text { Implementer's } \\
\text { enthusiasm/willingness, interest, zeal } \\
\text { and zest toward the assigned job. }\end{array}$ \\
\hline 8. & $\begin{array}{l}\text { Skills and } \\
\text { Abilities }\end{array}$ & $\begin{array}{l}\text { Implementer's intrinsic } \\
\text { abilities. }\end{array}$ & $\begin{array}{l}\text { Education and skill levels, HRD } \\
\text { practices (training mechanism). }\end{array}$ \\
\hline 9. & Trust & $\begin{array}{l}\text { Users believe in e- } \\
\text { government products. }\end{array}$ & $\begin{array}{l}\text { User's confidence level, its } \\
\text { dependency and reliability level on e- } \\
\text { government. }\end{array}$ \\
\hline 10. & $\begin{array}{l}\quad \text { Successful e- } \\
\text { government } \\
\text { policy } \\
\text { implementation. }\end{array}$ & $\begin{array}{l}\text { Meet the targets sets in } \\
\text { statute or executive order or } \\
\text { planned activity. }\end{array}$ & $\begin{array}{l}\text { User's satisfaction, acceptability, } \\
\text { reliability, easiness, and understanding } \\
\text { level determine the success of policy } \\
\text { implementation. }\end{array}$ \\
\hline
\end{tabular}

The reliability of summated scale is very important in survey research. Variables derived from test instruments are considered reliable only if they produce stable responses on a repeated administration of the test (Santos, 1999). Therefore, the consistency of measurement scale is ensured using Cronbach's Coefficient Alpha. According to Gable and Wolf (1993), the Coefficient value of above 0.7 is accepted for internal reliability of a scale. 
In this study, both independent and dependent variables have been measured through a five point Likert Scale. Therefore, Cronbach's Coefficient Alpha has been calculated using SPSS for these items. The following tables show the internal consistency and validity results.

\section{Table 2: Reliability Statistics}

\begin{tabular}{|l|l|l|}
\hline $\begin{array}{c}\text { Cronbach's } \\
\text { Alpha }\end{array}$ & $\begin{array}{c}\text { Cronbach's Alpha Based on } \\
\text { Standardized Items }\end{array}$ & N of Items \\
\hline .870 & .885 & 10 \\
\hline
\end{tabular}

The reliability among the variables is 0.870 , which seems to be a good sign for internal consistency among the variables.

Regression analysis is a common and versatile statistics technique in the social sciences. It allows researchers to examine the nature and strength of the relations between the variables and the relative predictive power of several independent variables on a dependent variable. Therefore, in this study, linear regression has been used to examine the relationship between different factors and to examine hypothesizes.

Regression test is conducted with survey data of independent variables and dependent variable. The results of regression analysis are determined from the values of certain indicator; first value of "R Square" and "Adjusted R Square" are judged in relation to 1.0 value. Second, t-stat, coupled with its p-value, indicates the statistical significance of the relationship between the independent variable; $t$-stat of greater than 1.96 is significant whereas p-value of less than 0.05 indicates that the independent variable is a significant predictor of the dependent variable. However, the p-value alone may not be considered an indicator of the dependent variable. Additionally, the highest beta coefficient indicates the highest amount of influence of independent variables over the independent variable (Boslaugh and Watters, 2008).

R-Squared and Adjusted R-Squared are both statistics derived from the regression equation to quantify model performance. The value of R-squared ranges from 0 to 100 percent. According to regression results shown in Table 4.9, Adjusted R-Square $=0.800$, which means that this model explained $80 \%$ of the variation in the dependent variable whereas $20 \%$ is unexplained. Similarly, demographic data (management level, age, education level, and work experience) depicts that there is no significant relationship with successful implementation of e-government policy implementation.

Table 3: Empirical Results

\begin{tabular}{|c|l|l|l|r|} 
Dependable Variable & $\begin{array}{l}\text { Un- } \\
\text { standardized } \\
\text { Coefficient }\end{array}$ & $\begin{array}{c}\text { Standard } \\
\text { Error }\end{array}$ & $\begin{array}{c}\text { Standardize } \\
\text { d Coefficients }\end{array}$ & p-value \\
\hline
\end{tabular}




\begin{tabular}{|c|c|c|c|c|}
\hline E-Leadership & .256 & .146 & .161 & .083 \\
\hline Policy Elucidation & -.632 & .143 & -.381 & .000 \\
\hline Strategic Planning & .651 & .136 & .422 & .000 \\
\hline Resourcing & .213 & .073 & .230 & .004 \\
\hline $\begin{array}{l}\text { Communication and } \\
\text { Coordination }\end{array}$ & .250 & .096 & .222 & .011 \\
\hline $\begin{array}{l}\text { Role Delineation with } \\
\text { Accountability }\end{array}$ & -.082 & .112 & -.038 & .468 \\
\hline $\begin{array}{l}\text { Commitment and } \\
\text { Motivation }\end{array}$ & -.303 & .058 & -.273 & .000 \\
\hline Skills and Abilities & .434 & .077 & .394 & .000 \\
\hline Trust & .120 & .037 & .164 & .001 \\
\hline \multicolumn{5}{|l|}{ Demographic Data } \\
\hline Management Level & .117 & .106 & .056 & .272 \\
\hline Age & -.022 & .010 & -.180 & .026 \\
\hline Education & .001 & .048 & .001 & .984 \\
\hline Experience & -.004 & .010 & -.034 & .675 \\
\hline \multicolumn{5}{|l|}{ Summary } \\
\hline $\mathrm{N}$ & 119 & & & \\
\hline F- Value & 53.349 & & & \\
\hline Adjusted R Square & 0.800 & & & \\
\hline Alpha Value & 0.870 & & & \\
\hline
\end{tabular}

The most influential variables for successful implementations of e-government policy are "strategic planning", "skill and ability" and "trust" factors with successful e-government policy implementation. 
The questions asked in the interviews were mainly about the critical success factors affecting egovernment policy implementation in Pakistan and research questions or hypothesizes.

E-government cannot be implemented without the commitment of top leadership, in particular financial commitment, as e-government projects require huge funds. This dedication is missing in top leadership (Qaisar and Khan, 2010).

Major policies implementation programmes in Pakistan are run on foreign support. Donor agencies dictate their terms and conditions from time to time, which reflects weakness of leadership. For example, the recently introduced higher education reforms appear to be influenced by the report of the International Task Force on Higher Education, which was prepared under the auspices of the World Bank and UNESCO (Pakistan, Ministry of Education, 2002; The Task Force on Higher Education and Society, 2000).

Weak administration and poor implementation mechanisms also result in policy implementation failure. For example Basic Health Units (BHUs), which are situated in villages, have residential quarters for the doctor and the Lady Health Visitors (LHV). The doctor and the staff do not want to live on site due to lack of facilities in rural areas; they prefer to come daily from cities to their place of work, which results in higher absenteeism (Khan., 2009, pp.13-17; Noorzai, 2012; Government of Pakistan, 1998). Benazir Income Support Programme (BISP) is succeeding only due to top leadership interest and political will (Gazdar, 2011).

Ali (2006) notes that causes of education policy failure are due the fact that most of the education policy makers believe that implementation is encapsulated in policy formation. This phenomenon results in a wide gap between ground realities with policy statute and its directives. Lack of precise, accurate, consistent, stable, simple and clear policy directives results in a poor implementation of education policy (Akbar, 1995; Bukhari, 1995). In case of health policy implementation, there is an exceptional gap between policy formulation and its implementation as most of the work is done at the central level and the local implementer merely receives unclear directive- and policy guidelines without knowing the exact objectives and pros and cons of the policy (Noorzai, 2012; Khan, 2006; 2009).

According to Naeem (2003), the Ministry of Information Technology has taken ownership of the e-government and e-commerce drive as part of its Information Technology Policy. Due to a lack of strategic planning against IT policy, the future of e-commerce remains unclear. Similarly, absence of reliable historical data results in ambitious target setting in policy strategy (Ahsan, 2003; The World Bank, 1999). In 2002, the government of Pakistan recognized that there are inconsistencies in educational statistics and has since given assurances that this will be corrected (Jamil et al., 2002, p. 8).

Similarly, most of the strategies developed against policies in Pakistan are centre oriented which creates a gap between policy and practice and creates a lack of social, religious and cultural values. This results in ambiguous target setting. For example, educational initiatives at grassroots level are strange to the educational managers, the local implementer (Ahsan, 2003, p. 276; Memon, and Wheeler, 2000, pp. 3-4; SPDC, 1997, pp. x-xi; AKUI and DID, 2003, pp.3-12). Similarly, health 
reforms were introduced in 2001, which focused on a preventive health care model. These reforms focused on new hospitals and modern technology and equipment rather than health issues such as public health and public safely among others. Everything was happening only on paper; it was not implementable on the ground (Siddiqui et al 2004; Khan 2006, p. 98-99).

When family planning programmes were launched in Pakistan, the religious groups opposed it on the ground that it is contrary to Islamic values and this resulted in total failure (Khan, 2009, pp. 19-32; Lee, et al., 1998; Thatcher and Rein, 2004, pp. 457-481; Dolowitz and Marsh 2000, pp. 5-21).

National Social Protection Strategy (NSPS) is succeeding due to strong strategic planning, as the planning phase took almost one and a half year (2006-mid-07) for building an acceptable implementation mechanism (Gazdar, 2011).

Education policy implementation under the umbrella of Social Action Programme (SAP) required community participation in the form of parent teachers (local school management) associations. As most of associations were created in haste without proper training and resourcing, this resulted in failure of getting the expected benefits particularly at local schools level (SPDC, 1997, p. xii ; Ali, 2006).

Pakistan spends almost twice on each student on primary and secondary education compared to other developing countries. Nevertheless, governments still do not achieve targets set in National Education Policy (1998-2010).

The government has made different health initiatives from time to time. The policy always focuses on new health facilities, laboratories, ambulances and equipment without assessing how it will be used by the health sector without prior HRD and planning (Khan, 2006; Noorzai, 2012).

National Education Policy (2009) reports that weak policy implementation is primarily due to allocation and utilization of resources (Ahmed et al., 2012). Furthermore, up to ten to thirty percent of developmental funds remain unspent in Pakistan (Rasool, 2007). BISP programme have succeeded despite limited resources (Gazdar, 2011).

Electronic Government Directorate (EGD) has prioritized the 40 projects under the umbrella of "introducing e-governance in government departments and ministries". The major task of EGD was to digitalize the daily working and existing data by establishing different software applications, databases, and networks thus establishing a virtual and paperless working environment in government offices. An amount of PKR 2.5 billion (USD 26 million) was allocated for these projects, but only PKR 1.14 billion (USD 11 million) was utilized from 2002 to June 2008 (Ahmed, 2012). Most of the projects were badly trapped in the planning phase. Only few of them emerged out of the embryonic phase to a stage of partial implementation.

E-government and health policy failure in Pakistan is due to a lack of coordination among the centre with other levels of government (Khan, 2006, pp. 97-100; Khan, 2009, p. 7; Qaisar and Khan, 2010; Noorzai, 2012). According to Noorzai (2012), the implementation of health policies is the prime responsibility of the district government, but the federal government directly intervenes 
through its vertical programmes, such as the national program for family planning and primary healthcare, the expanded program of immunization; the national aids control programme, the malaria control programme, the national nutrition programme, and the hepatitis control programme. These vertical programmes are implemented at the primary health units and manage directly by federal government, thus by passing other local governments (Nishtar, 2007, p. 63-73).

Benazir Income Support Programme (BISP) has succeeded due to good coordination between Benazir Income Support Programme (BISP) and Nation Database and Registration Authority (NADRA) (Gazdar, 2011).

After Pakistan was founded, the new government discontinued most of the programmes from the previous government after assuming power, so civil bureaucracy became prevalent, reducing the accountability of assigned jobs. (Ahsan, 2003, pp. 264-266). According to (Ali, 2006), the devolution plan in Pakistan creates tension between provincial and district governments due to a lack of clarity of the relationship between the stakeholders (AKUI and DID, 2003, p. 5). Also mentioned as serious governance issues affecting proper implementation of development programmes are a lack of proper accountability mechanisms, excessive transfers and corruption (SPDC, 1997; The World Bank, 1999). For example, until May 2000 the average tenure of a federal education secretary was 8 months. In case of health policy implementation, the whole process lacks monitoring and evaluation mechanisms (Khan, 2009, pp. 7-10; Noorzai, 2012). The education sector in Pakistan is also adversely affected due to devolution plans, as they do not find clear-cut responsibilities. In Pakistan sometimes an uneducated person is surprisingly appointed as the head of a ministry or department (Khan, 2007). For example, the previous Federal Minister of Education holds fake degrees. This issue goes all the way down to the bottom of government machinery. Due to a lack of check and balance and accountability mechanisms, these people survive in public sector very effectively (Kelegai and Middleton.2003, Kundi et al., 2008; Ahmed et al., 2012; Zaki, 1992).

Every incoming government adapts new programmes by negating the existing ones. For example, a literacy project, titled "Nai Roshni" (new light) was launched in 1987 and was discontinued in 1989 with the change of government (Ahsan, 2003, p. 264). Due to change in the top leadership commitment, implementation consistency and continuity breaks which results in implementation failure (Akhtar, 2004, p. 176).

For example, instead of functioning on a five-year development plan, the government introduced a three-year poverty reduction strategy, which focuses mainly on economic revival, good governance, poverty alleviation and devolution, where education and other mainstream programmes are considered a subset of poverty alleviation programme (Ahsan, 2003, p. 270).

Due to little involvement of lower level managerial staff in the education sector, education policy fails in the implementation process (National Education Policy, 2009; Butt, 1996). Furthermore, due to poor commitment of implementers at all levels, funds of up to ten to thirty percent remain unspent in the education sector (Rasool, 2007). 
In 2000, the government of Pakistan showed tangible progress in the Information and Communications Technology (ICT) field. As a result of the National IT Policy and Action Plan, the government encouraged the importation of ICT equipment by significantly reducing custom duties, tax reduction for ICT businesses, and providing cheap internet and bandwidth rates (800 cities/towns/villages was connected) (August, 2000). Since then the IT growth rate has been falling as government priorities have shifted. This has also resulted in e-government implementation failures (Naeem, 2003).

In Basic Health Units (BHUs) which serves at village level, most of those appointed are not qualified as health professionals and are even not well skilled. This is the main reason of failure of many health programmes. Government initiatives will not succeed unless human capital is skilful and qualified (Ghaffar, 1992; Noorzai, 2012).

Electronic Government Directorate (EGD) was established in October 2002 with the mandate of establishment of e-government. However, due to lack of skills and ineffective training mechanism, huge government investment in EGD are unable to produce effective results (Saad, 2008; Qaisar and Khan, 2010). Quality of education of public and private institutions in Pakistan is questionable. For example, most of the IT education is incompatible with the market demands (Kundi, 2006).

People's trust in launched e-service is quite weak, as established ICT infrastructure does not support e-government application across the country (Qaisar and Khan, 2010). Most of the employees in the public sector prefer to work manually rather than electronically; reliance on ICT in the public sector and the general public is also weak (Saad , 2008). This is the main reason for malfunctioning of e-government in Pakistan (Argyris, and Schon, 1978; Kandelin et al. 1998; Bronjolfsson, 1993; 1998; Kundi, 2006;Kundi et al.,2008).

Trust deficit between finance and education ministries has resulted in failure of Social Action Programme (SAP) as all ongoing initiatives ceased due to non-availability of funds. (World Bank. Human Development Sector Unit, 2003, p. 16).

People have shown resistance to using computers for different available government online services. They rely more on offline rather than online services due to a lack of trust, reliability issues, and quality of services (Qaisar and Khan, 2010).

The summarized results are as follows:

Table 4: Results

\begin{tabular}{|c|c|c|c|c|c|}
\hline $\begin{array}{c}\text { Sr. } \\
\text { No: }\end{array}$ & Hypothesis & $\begin{array}{c}\text { Survey } \\
\text { Results }\end{array}$ & $\begin{array}{c}\text { Intervie } \\
\text { w Results }\end{array}$ & $\begin{array}{c}\text { Literature } \\
\text { Results }\end{array}$ \\
\hline 1. & H1.a & $\begin{array}{l}\text { E-leadership's role is } \\
\text { likely to have a positive } \\
\text { effect on successful e- } \\
\text { government policy } \\
\text { implementation. }\end{array}$ & Accepted & Accepte & Accepted \\
\hline
\end{tabular}




\begin{tabular}{|c|c|c|c|c|c|}
\hline 2. & H1.b & \begin{tabular}{l}
\multicolumn{1}{c}{ Clear and consistent } \\
policy guidelines are likely \\
to have a positive effect on \\
successful e-government \\
policy implementation.
\end{tabular} & Rejected & Rejected & Accepted \\
\hline 3. & H1.c & $\begin{array}{l}\text { Strategic planning is } \\
\text { likely to have a positive } \\
\text { effect on successful e- } \\
\text { government policy } \\
\text { implementation. }\end{array}$ & Accepted & $\mathrm{d}^{\text {Accepte }}$ & Accepted \\
\hline 4. & H2.a & $\begin{array}{l}\text { Proper and appropriate } \\
\text { resourcing is likely to have } \\
\text { a positive effect on } \\
\text { successful e-government } \\
\text { policy implementation. }\end{array}$ & Accepted & $\mathrm{d}^{\text {Accepte }}$ & Rejected \\
\hline 5. & H2.b & $\begin{array}{l}\text { Strong communication } \\
\text { and coordination is likely } \\
\text { to have a positive effect on } \\
\text { successful e-government } \\
\text { policy implementation. }\end{array}$ & Accepted & $\mathrm{d}^{\text {Accepte }}$ & Accepted \\
\hline 6. & H2.c & $\begin{array}{l}\quad \text { Role delineation with } \\
\text { accountability is likely to } \\
\text { have a positive effect on } \\
\text { successful e-government } \\
\text { policy implementation. }\end{array}$ & Rejected & $\mathrm{d}^{\text {Accepte }}$ & Accepted \\
\hline 7. & H3.a. & $\begin{array}{l}\quad \text { Strong commitment and } \\
\text { motivation are likely to } \\
\text { have a positive effect on } \\
\text { successful e-government } \\
\text { policy implementation. }\end{array}$ & Rejected & $\mathrm{d}$ Accepte & Accepted \\
\hline 8. & H3.b & $\begin{array}{l}\quad \text { Skills and abilities are } \\
\text { likely to have a positive } \\
\text { effect on successful e- } \\
\text { government policy } \\
\text { implementation. }\end{array}$ & Accepted & $\mathrm{d}$ Accepte & Accepted \\
\hline 9. & H3.c. & $\begin{array}{l}\text { Citizens' trust in e- } \\
\text { government is likely to } \\
\text { have a positive effect on } \\
\text { successful e-government } \\
\text { policy implementation. }\end{array}$ & Accepted & $\mathrm{d}^{\text {Accepte }}$ & Accepted \\
\hline
\end{tabular}

\section{Conclusion}

The government of Pakistan has paid a lot of attention towards e-government and developed different policies in order to create a good governance mechanism. Most of the approved e-government policies have failed at the policy implementation stage. This study highlights different aspects and approaches of successful e-government policy implementation based on a 
literature review. It also identifies some critical factors that determine the failure of policy implementation in Pakistan. The proposed model consists of nine independent factors, which are grouped in to three categories: Organization Oriented Factors, Process Oriented Factors and People Oriented Factors with one dependent factor: successful e-government policy implementation. Furthermore this study proposes a model which is based on nine successful factors: E-leadership, Policy Elucidation, Strategic Planning, Resourcing, Communication and Coordination, Role Delineation with Accountability, Commitment and Motivation, Skills and Abilities, Trust as independent variables and success of e-government successful policy implementation as dependent variable. Nine hypothesizes are developed in context with each nine independent variables with one dependent variables. These factors are validated by analyzing different hypothesizes by using empirical analysis, i.e., quantitative and qualitative along with findings from different case studies of policy implementation in Pakistan. Five factors: Eleadership, Strategic Planning, Communication and Coordination, Skills and Abilities, Trust are identified as more critical and influential in building e-government policy.

The aim of this research is to turn e-government policy into practice in two ways. Firstly to distil the lessons from existing evidence and experience about e-government implementation of policies and secondly, by assessing the quality of the evidence, gaps that need to be filled and ways that research findings can support implementation process in Pakistan. A main question, therefore, is how far national policy aspirations translate effectively into actions that are meaningful and measurable at a local level. This means the consistency of the goals at all levels remain the same, i.e., the macro level and micro levels.

This study provides a fair idea about intrinsic and extrinsic behaviour of these successful factors towards e-government policy implementation concerning Pakistan. This study also facilities in successful e-government implementation in Pakistan by setting direction and guidelines for all implementation stakeholders. It is also beneficial for policy makers of developing countries in general and Pakistan in particular, before embarking a promising journey of e-government policy implementation. This study also proposes some recommendations that may be useful for all levels of e-government policy implementation.

\section{References}

Agha Khan University Institute for Educational Development, and Department for International Development, Policy Dialogues on Key Issues in Education. (2003). Karachi.

Ahmed, S. (2012).The internet and corruption Failures of governance. url: http://www.bytesforall.pk.

Ahsan, M. (2003).An analytical review of Pakistan's educational policies and plans. Research Papers in Education, 18(3), 259-280.

Akbar, A. (1995). Plan Implementation and Management. AIOU, (Unit2), Islamabad, 33-39.

Akhtar, S. (2004). An econometric evaluation of Pakistan's National Education Policy 1998-2010. Journal of Educational Planning and Administration, 18(2), 175-197. 
Ali, S. (2006). Why does policy fail? Understanding the problems of policy implementation in Pakistan - a neuro-cognitive perspective. International Studies in Educational Administration, 34(1), Volume 34, Number 1, 2006.

AlNuaimi, M., Shaalan, K., Alnuaimi,M., and Alnuaimi, K. (2011).Barriers to electronic government citizens' adoption: A case of municipal sector in the emirate of Abu Dhabi in Developments in Esystems.Engineering (DeSE).

Sobhi, A, Weerakkody, V., and Kamal, M.M. (2010). An exploratory study on the role of intermediaries in delivering public services in Madinah city: Case of Saudi Arabia. Transforming Government: People, Process and Policy, 2010. 4(1): p. 14-36.

Argyris, C. and Schon, DA. (1978). Organizational learning. A theory of action perspective. Addison-Wesley, 23-29.

Awadhi,S.A., Moris, A.(2008).The use of the UTAUT model in the adoption of e-government services in Kuwait. Paper presented at Hawaii International Conference on Sytem Services, Hawaii.

Balockaite, R., Morkevicius V., Vaidelyte, E., and Zvaliauskas, G. (2008). The Impact of New ICTs on Democracy: Positive and Negative Scenarios. Socialiniai Mokslai, 1 (59).

Belanger, F. and Carter,L. (2008).Trust and risk in e-government adoption. The Journal of Strategic Information Systems, 17(2), 165-176.

Behrens, S.J., (1994). A conceptual analysis and historical overview of information literacy. College and Research Libraries, 1994. 55(4), 309.

Boslaugh, S. and Watters, P.A. (2008). Statistics in Nutshell. O'Reilly Media,Inc.,Sebastopol,CA, 95472.

Bukhari, M. A. (1995). Plan Implementation and Management (Unit 16), AIOU, Islamabad, 113-118.

Butt, R. (1996). Failures in the Achievements of Targets in Five Year Plans with Preferences to Secondary Education in Pakistan (Unpublished). AIOU,

Bronjolfsson,E.(1993).The productivity paradox of information technology.Communications of the ACM, 36 (12), 67-77.

Brynard P.A. (2005). Policy Implementation: Lessons for Service Delivery. African Association for Public Administration and Management, 27th AAPAM Annual Roundtable Conference, Livingstone, Zambia, 5th - 9th December 2005.

Colesca,S.E,(2009).Understanding Trust in e-Government. ISSN 1392 - 2785, Inzinerine EkonomikaEngineering Economics(3),2009,Economics of Engineering Decisions ,Research Centre in Public Administration and Public Services, Academy of Economic Studies, Bucharest, Romania, Calea Serban Voda 22-24, Bucharest, Romania, sofiac@man.ase.ro.

Dada, D. (2006).The failure of e-government in developing countries: A literature review. The Electronic Journal of Information Systems in Developing Countries, 26 (7), 1-10.

Dolowitz, D. and Marsh. (2000).Learning from abroad: the role of policy transfer in contemporary policymaking. Governance: An International Journal of Policy and Administration, vol. 13, no. 1, 5-24. 
Edwards, G. C. (1980). Implementing Public Policy. Washington D.C.,Congressional Quarterly Press.

Economist Intelligence Unit Limited. (2010).Enabling efficient policy implementation. A report from the Economist Intelligence Unit Sponsored by Oracle, Economist Intelligence Unit Limited 2010.

Firestone, W.A. (1989). Using reform: Conceptualizing district initiative. Educational Evaluation and Policy Analysis, 11 (2), 151-164

Flores, W.R. and Gevriye, M. (2011). Surveying experts on IT governance factors and their impact on underlying goals. In the Proceedings of 8thInternational Conference on Enterprise Systems, Accounting and Logistics (ICESAL'11), Thassos Island, Greece, 11-12 July 2011.

Gable R.K. and Wolf, M.B. (1993). Instrument Development in the Affective Domain, Kluwer Academic Publishers, 2nd Edition, Boston.

Gazdar,H.(2011).Social protection in Pakistan: in the midst of a paradigm shift?.CSP, Research Report 13.January 2011.

Ghaffar, S. A. (1992). Development of education in the decade 1980-90 in Pakistan. Journal of Rural Development and Administration, XXIV, 75-91.

Giacchino,S., and Kakabadse, A. (2003).Successful policy implementation: the route to building self-confident government. International Review of Administrative Sciences, [0020-8523(200306)69:2], SAGE Publications, (London, Thousand Oaks, CA and New Delhi), Vol. 69 (2003), 139-160.

Gichoya, D. (2005). Factors Affecting the Successful Implementation of ICT Projects in Government. The Electronic Journal of e-Government, Volume 3, Issue 4, 175-184, available online at www.ejeg.com.

Government of Pakistan. (2009). National Education Policy 2009. Ministry of Education, Islamabad.

Government of Pakistan. (1998). National Education Policy 1998-2010, Ministry of Education, Islamabad.

Giacchino, S. and Kkabadse, A. (2003). Successful Policy Implementation: the Route to Building SelfConfident Government. International Review of Administrative Sciences, 69(2), 139-160pp.

Hameed, T. (2007). ICT as an enabler of socio-economic development. Retrieved June, 24, 2007.

Heeks, R. (2003).Design-Reality Gap Assessment: eGov Risk Assessment Technique 2. U e-Government for Development. Manchester, UK, Commonwealth Telecommunications Organsation and University of Manchester Institute for Development Policy and Manaement, (2003), 2004.

Hill, M.J. and Hupe, P.L. (2002/2009 Implementing Public Policy: An Introduction to the Study of Operational Governance. 2nd ed, London: Sage.

Hunter, B.(1983). My students use computers: Learning activities for computer literacy. Reston Publishing Company, 11480 Sunset Hills Road, Reston, VA 22090.

James, P. S., Brian, J. R., and Todd, R.(2002).Policy Implementation and Cognition: Reframing and Refocusing Implementation Research. Review of Educational Research Fall 2002, Vol. 72, No. 3, 387431. 
Jamil, B. R., and Qureshi, T. M. (2002). Policy Dialogue on Decentralization. Paper presented at the Research and Policy Dialogues on Key Issues in Education, Decentralization in Education, Karachi.

Kandelin, N.A., Lin, T. and Muntoro, K. (1998). A study of the attitudes of Indonesian managers toward key factors in Information System Development and Implementation. Journal of Global Information Management, 6 (3), 17-26.

Kelegai, L. and Middleton, M. (2003). Factors Influencing Information Systems Success in Papua New Guinea Organizations: a Case Analysis. Proceedings of 5th International IT in regional Areas Conference at Queens land, Australia,15-17 December, 2003,113-124.

Khan, M.A. (2009). Failure analysis of primary health care in Pakistan and recommendations for change. Insaf Research Wing, Islamabad, 2

November,2011,http://www.insaf.pk/Portals/0/webmgmt/irw/FAILURE\%20ANALYSIS\%20\%20\%2 06-28-09.pdf.

Khan, M.M. (2006). Health policy process and health outcome: the case of Pakistan: health policy analysis. Eastern Mediterranean Health Journal, viewed 2 November 2011,http://dissertations.ub.rug.nl/Files/faculties/medicine/2006/m.m.khan/c7.pdf.

Kiviniemi, M. (1986). Public policies and their targets: a typology of the concept of implementation. International Social Science Journal, 38(2), 251. Retrieved September 24, 2009, from Academic Search Complete database.

Kharel.P. and Shakya,S.(2012).E-Government Implementation in Nepal : A Challenges. International Journal of Advanced Research in Computer Science and Software Engineering. Volume 2, ISSN: 2277 128X, Issue 1, January 2012.

Kundi, G. M., Shah, B., Nawaz, A. (2008).Digital Pakistan: Opportunities and Challenges. Journal of Information Systems and Technology Management, Vol. 5, No. 2, ISSN online: 1807-1775, 365-390.

Kundi, G.M. (2006). E-Business in Pakistan: Opportunities and Threats. Un-published PhD dissertation in management studies, Department of Public Administration, Gomal University, D.I.Khan, Pakistan, 1087.

Lee, J. Y., and Anderson, C. (2012). Cultural policy and the state of urban development in the capital of South Korea. The Politics of Urban Cultural Policy: Global Perspectives, 40, 69.

Lee, K., Lush, L., Walt, G. and Cleland, J. (1998). Family planning policies and programs in eight low income countries: a comparative policy analysis. Social Science and Medicine, vol.47, no. 7, 944-959.

Lean, O.K., Zailani, S., Ramayah, T., Fernando, Y. (2009). Factors influencing intention to use e-government services among citizens in Malaysia. Int. J. Info. Manage, 29(6), 458 - 475.

Maciaszek, L.A. (2001). Requirements analysis and system design : developing information systems with UML. Harlow, Addison-Wesley.

Makinde,T. (2005).Problems of Policy Implementation in Developing Nations: The Nigerian Experience. J. Soc. Sci., 11(1): 63-69. 
Matland, R.E. (1995). Synthesizing the Implementation Literature: The Ambiguity-Conflict Model of Policy Implementation. Journal of Public Administration Research and Theory: J-Part, Vol.5, No.2. (April. 1995),145-174

May.P, (2008).Implementation and Bureaucratic Politics.Political Science 573A,Smith Hall rm 107,Autumn 2008,http:/faculty.washington.edu/pmay/pols573.

Mazmanian, D. A., and Sabatier, P.A. (1983). Implementation and Public Policy. Glenville, III: Scott, ores man, (Republished in 1989 by University Press of American, Lanham, Md.)

Miles, M.B. and Huberman, A.M. (1994). Qualitative Data Analysis, 2nd Edition. Newbury Park, CA, Sage Publication.

Mustafa, S. (2004).Learning something from past mistakes. 21 November, 2004, Daily Dawn.

Nagy, K.H.,Christine, Z.W.,Kaoru, K.S., (2009).National E-Government Institutions: Functions, Models, and Trends. Information and Communications for Development, 2009.

Naeem, A. (2003).Capacity-Constraints on E-Commerce in Pakistan. Quarterly Science Vision, Vol.8, (3and4) January - June, 2003.

Nishtar, S.(2007). Health indicators of Pakistan. Gateway paper 11, Heart file, Islamabad, viewed 28 October 2011,http://www.heartfile.org/pdf/GWP-11pdf.

Noorzai.K.(2012). Failure analysis of health policy of Pakistan. http:/ /healthpolicypak.blogspot.kr/2012/05/ failure-analysis-of-health-policy-of.html, Friday, 18 May 2012.

O'Toole, L.J. (1986). Policy recommendations for multi-actor implementation: An assessment of the field. Journal of Public Policy, 6,181-210.

O'Toole, L. (2000). Research on Policy Implementation: Assessment and Prospects. Journal of Public Administration Research and Theory, 10, 263-288.

Brynard, P.A. (2009).Mapping The Factors That Influence Policy Implementation. Journal of Public Administration, Vol 44, no 3.1.

Pakistan, Ministry of Education. (2002). Education Sector Reforms: Action Plan 2001 - 2004. Islamabad, Government of Pakistan.

Palumbo, Dennis, J., and Donald, J. (1990). Implementation and the Policy Process, opening the Black Box. Greenwood Press, New York, Wet port.

Paudel, R. N. (2009). Nepalese Journal of Public Policy and Governance. Volume xxv, No.2, December, 2009.

Pressman, J.L., and Wildavsky, A. (1984), Implementation: 3r Edition. Bekeley: University of California Press.USA.

Qaisar, N., and Khan, G. (2010). E-Government Challenges in Public Sector: A case study of Pakistan. IJCSI International Journal of Computer Science Issues, Vol. 7, Issue 5, September 2010.ISSN (Online): 16940814.www.IJCSI.org. 
Rasool, G. (2007). Evaluation of Educational Policies, (Un-Published Master's Thesis).

Robichau, R., and Lynn, J. L. (2009, February). The implementation of public policy: Still the missing link. Policy Studies Journal, 37(1), 21-36. Retrieved September 24, 2009, doi:10.1111/j.1541-0072.2008.00293.x

Saad, K. (2008). Where is e-Government in Pakistan? Green and White Blog, http://greenwhite.org/blog/2008/10/09/where-is-e-government-in-pakistan/.

Santos, J. R. (1999).Cronbach's Alpha: A tool for Assessing the Reliability of Scales. Journal of Extension, $37(2)$.

Shull, S., and Garland, D. (1995). Presidential influence versus agency characteristics in explaining policy implementation. Policy Studies Review, 14(1/2), 49-70. Spring/Summer, 1995-Retrieved September 24, 2009, from Academic Source Premier database.

Siddiqui, S., Haq, Ghaffar, Akhtar, T., and Mahaini, R. (2004). Pakistan's maternal and child health policy: analysis, lessons and the way forward. Health Policy, Vol. 69, no.1, 117-130.

Snellen, I. (2000). Electronic commerce and bureaucracies. In the Proceedings of the 11th International Workshops on Database and Expert System Application,285-288.

SPDC. (1997). Review of Social Action Program. Summary Report, Karachi: Social Policy Development Centre.

Sprecher, M. (2000). Racing to e-government: Using the Internet for citizen service delivery. Government Finance Review, 16, 21-22.

Sulaiman, A. A., Richard, M. C., Gary, B. W. (2012).Towards an integrated model for citizen adoption of Egovernment services. International Journal of Information Technology and Computer Science, IJITCS, ISSN No: 2091-1610, Volume 6: Issue on November / December, 2012.

Tan, K.S., Teo, W.L. and Lai, K.P. (2011). The applicability of information technology governance in the Malaysian SMEs. Journal of Innovation Management in Small and Medium Enterprises, 2011(2011), 110.

Terpestra, J., and Havinga, T. (2001). Implementation between tradition and management: Structuration and styles of implementation. Law and Policy, 23(1). January 2001, Retrieved September 24, 2009, from Academic Search Complete database.

Thatcher, D., and Rein, M. (2004). Managing value conflict in public policy; Governance. An International Journal of Policy, Administration and Institutions, vol. 17, no. 4, 457-486.

UNESCO. (2000). Higher Education in Developing Countries: Peril and Promise. The Task Force on Higher Education and Society Washington: World Bank, The United Nations Educational, Scientific and Cultural Organization (UNESCO).

The World Bank. (1999). Implementation Completion Report (Core ICR) on a credit in the amount of US\$112.5 million to the Islamic Republic of Pakistan for a Sindh Primary Education Development Program. IDA Credit 2102-PAK, Unpublished: Education Sector Unit south Asia Region. 
Thomas, B. S., (1973).The Policy Implementation Process. Policy Sciences 4(1973), 197-209. Elsevier Scientific Publishing Company, Amsterdam-Printed in Scotland.

UN and ASPA. (2001). United Nations and American Society for Public Administration Global survey of egovernment.

Van, M., Donald, S., and Van, H.C. (1975). The Policy Implementation Process: A conceptual Framework. Administration and Society, Vol.6 No: 4, February 1975, 445-487.

World Bank Report. (2003). Human Development Sector Unit, 2003, p. 16.

Yildiz, M. (2006). Performance indicators and e-government projects: Evidence from Turkey. Department of Public Administration, Hacettepe University, Ankara, Turkey.

Zaki, W. M. (1992). Pakistan's Educational Quagmire. AIOU, Islamabad. P.03.

\section{About the Author}

\section{Waqar Siddique}

Waqar Siddique has 17 years plus practical and research based experience of public and private sector in ICT, Governance, ICT Policy Formation, particularly its implementation, Project Management, Management of Business IT and other appropriate education leading to a solid understanding and expertise in a diverse range of technologies and solid management skills. Waqar Siddique manages different information technology projects of national and regional levels with notable success in planning and implementation and is currently the director of Ministry of Information, Broadcasting and National Heritage. 